\title{
Effect of rhizobial inoculants on yield and yield components of faba bean (Vicia fabae L.) on vertisol of Wereillu District, South Wollo, Ethiopia
}

\author{
Samuel Adissie Gedamu1*, Enyew Adgo Tsegaye ${ }^{2}$ and Tesfaye Feyisa Beyene ${ }^{3}$
}

\begin{abstract}
Background: Nitrogen fixation by legumes like faba bean is a cheap way of fixing atmospheric nitrogen to plant available form. However, the inoculation of grain legumes with rhizobium bacteria are poorly researched in Amhara Region of Ethiopia.
\end{abstract}

Methods: Thus, a study to examine the effects of rhizobium leguminosarum (var vicae) strains on nodulation, growth, and yield of faba bean was conducted in Wereillu district of Amhara Region, Ethiopia during the rainy season of 2018. The treatments comprised of four levels of faba bean Rhizobium strains (un-inoculated, EAL-1018, EAL-1035 and EAL-17) arranged in a randomized complete block design with three replications. The collected data on yield and yield-related parameters were analyzed using Statistical Analysis System (Statistical Analysis System, version 9.1, SAS Institute Inc, Cary, 2003), version 9.1 and subjected to Duncan's Multiple Range Test for mean separation when the analysis of variance was significant.

Results: The result revealed that the effect of EAL-1018 brought significantly $(P \leq 0.05)$ higher difference on nodule number, nodulation volume, nodule dry weight, biomass yield and grain yield compared to the control. Faba bean strain, EAL-1018 gave 45.6, 27 and 11.6\% grain yield advantage over the control, EAL1017 and EAL 1035 respectively.

Conclusion: Biologically as well as Economically EAL 1018 brought the maximum yield and net benefit (47020.7) compared to the other treatments. Hence, EAL-1018 is recommended for the study area and similar agro-ecologies.

Keywords: Symbiosis, Faba bean, Strain, Legume

\section{Introduction}

\section{Background and justification}

Biological nitrogen fixation, which is the conversion of atmospheric nitrogen to ammonia by microorganisms in root nodules of legume plants, plays a significant role in the global nitrogen cycle and in world agriculture. The ability to fix nitrogen is widely, but sporadically

*Correspondence: sammy.ab1990@gmail.com

${ }^{1}$ Department of Natural Resource Management, Soil science, Sirinka Agricultural Research Center, P.O. Box 74, Woldiya, Ethiopia

Full list of author information is available at the end of the article distributed among Archaea and Bacteria which includes these families: Proteobacteria, Firmicutes, Cyanobacteria, Actinobacteria and Chlorobi (Santos et al. 2012).

Rhizobia establish symbiotic organs termed root nodules on the roots of their host, and proliferate by extracting nutrients from the host plant. In turn, they supply their host plants with nitrogen resources produced by nitrogen gas fixation (Fujita et al. 2014).

Faba bean (Vicia faba L.) is an important grain-legume crop and a good source of dietary protein (Hanelt and Mettin 1989). It is a major food and feed legume because of the high nutritional value of its seeds, 
which are rich in protein and starch (Duc et al. 2010). Next to China, Ethiopia has been the main producing country of faba bean. Ethiopia is also considered as the secondary Centre of diversity and also one of the nine major agro-geographical production regions of faba bean (Hailu et al. 2014).

Faba bean takes the first place among pulse crops' production cultivated in Ethiopia which is leading the protein source for the rural people and used to make various traditional dishes. According to CSA (2018) Faba bean takes over $3.45 \%$ of cultivated land with an average national productivity of 2.1 tons' ha- 1 . It is also the first among pulse crops cultivated in Amhara region and South Wollo zone with average productivity of 1.88- and 1.4-tons' ha-1 respectively (Statistical Analysis System 2003; CSA 2018). However, the optimal yield production in faba bean is dependent on symbiosis with Rhizobium leguminosarum to produce nitrogen-fixing root nodules as well as on the pollination services of wild bee populations to ensure both optimal seeds set and out crossing rates (Sullivan and Angra 2016).

Rhizobium symbiosis with legumes produces $50 \%$ of 175 million tons of total biological N2 fixation annually worldwide (Yadav and Verma 2014). As Herridge et al., (2008) reported, the symbiosis of rhizobia forms nodules on the roots or stems of the host plant and legume-rhizobia symbiosis accounts $60 \%$ of the total biological nitrogen fixation. Therefore, inoculation of legumes with efficient rhizobia is believed to increases the yield and yield components of legumes while maintaining soil health. It is also supposed to be ecofriendly practices used for improvement of $\mathrm{N}$ fixation resulted in increased shoot growth, number of pods, and grain yield of faba bean (Siczek and Lipiec 2016).

In Ethiopia, there is a gradual increase in chemical fertilizer usage without letting any crop and animal manure residues in farm land. This action leads to the distraction of microorganisms in the soil, poor soil structure, low nutrient and water holding capacity of soil and reduce soil fauna-flora distribution. To minimize these environmental and soil damages caused by chemical fertilizers, the contribution of biological nitrogen fixation while increasing crop production plays indisputable role especially in maintaining soil health. In Ethiopia, the use of bacterial strain is not well advanced due to the lack of considerable effective strain selection, production and lack of appropriate inoculation of strains on the field. The objective of this study is therefore to evaluate the effect of rhizobial inoculants on yield and yield components of faba bean.

\section{Materials and methods Description of the study area Location}

The study was carried out in Wereillu District, of South Wollo zone of the Amhara Region, Ethiopia. The experimental site is located at geographical coordinates of $10^{\circ}$ $40^{\prime} 6^{\prime \prime}$ latitude and $39^{\circ} 26^{\prime} 19^{\prime \prime}$ longitude at an altitude of $2662 \mathrm{~m}$ above sea level (m.a.s.l) (Fig. 1).

\section{Climate}

Wereilu is one of the highland districts of South Wollo. But it encompasses all kola, woina dega, dega and Wurch climatic zones sharing 2, 31, 64 and $3 \%$ of the district. The rainfall pattern is predominantly bimodal, the short (belg) rains falling from mid-January to the end of May and the main or kiremt rains falling from June to midOctober. Based on the last ten years (2008-2017) meteorological data obtained from Ethiopian Meteorological Service Agency, Kombolcha station, the district receives a mean annual rainfall of $873.0 \mathrm{~mm}$ with mean minimum and maximum temperatures of 10.3 and $21.6{ }^{\circ} \mathrm{C}$ respectively.

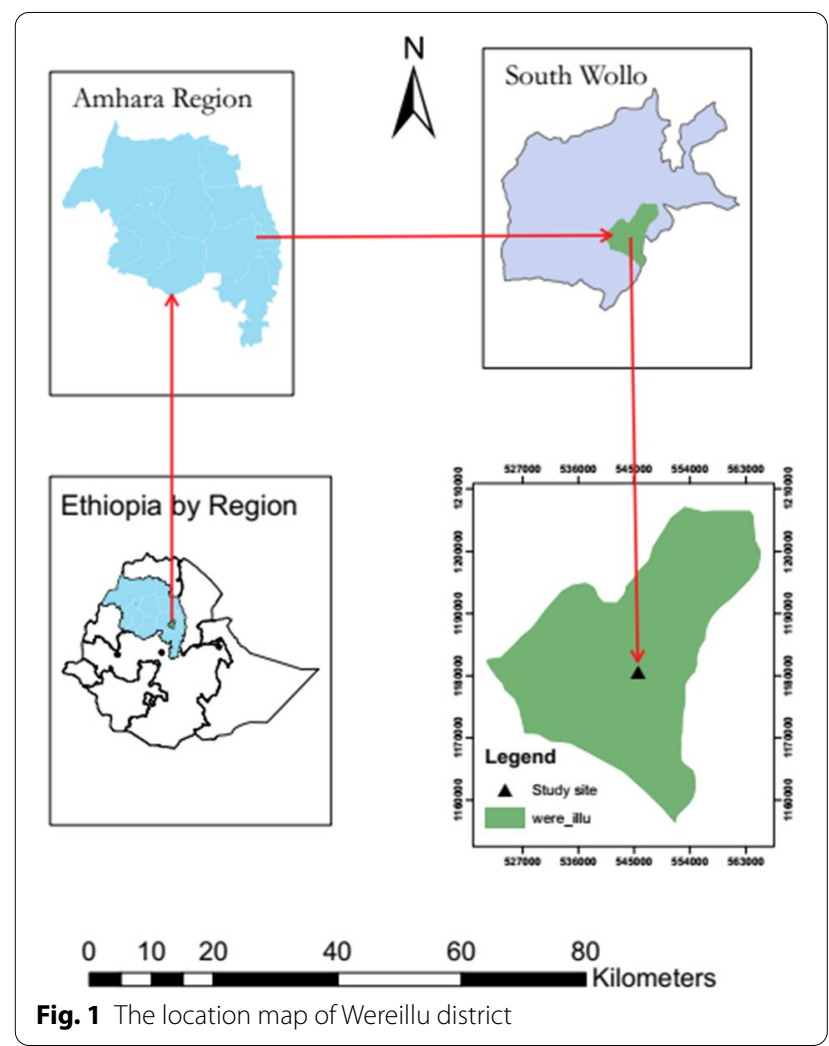




\section{Geology of the study area}

The geology of Eastern Amhara including the study area is covered by Cenozoic volcanic rocks with some sedimentary rocks (Kogal et al. 2012). The major formations are Ashangi, Tarmaber-Megezez, Alajae, Aiba basalts and Amba-Aradom formations covering 49, 18, 14, 12 and $3 \%$, respectively (Mengesha Tefera et al. 1996). The geology of the study area belongs to Tarmaber-Megezez formations. Tarmaber-Megezez formations are transitional and alkaline basalts (Tefera et al. 1996). According to FAO (1984) the soils of Wollo area have been developed almost exclusively on Trap Series volcano.

\section{Farming system of Wereillu district}

According to Wereillu district agriculture office (2011) Wereillu encompasses an area of 110,001 hectares of land, from which, 57,383 ha, 11,354 ha, 8767 ha of land are allocated for crop production, grazing, natural forest, and bush, respectively. The remaining unutilized and water bodies cover 8767 ha and 115.5 ha of land, respectively. Agriculture takes a greater part as a source of income for the farmers; however, it is unable to fully meet one of its most basic important functions i.e. the provision of food for the large and expanding population. Cereals as wheat (triticum aestivum L.), teff (eragrostis teff L.), pulse (fabciea L.) and other oil and spices are the source of food and cash income. There are two-production seasons (meher and belg). Meher is the main season and belg producing kebeles are small in number. Out of the total land allocated for crop production, 50,116 ha is used for meher and 7267 ha for belg production season. The remaining 770 ha of land is cultivated by using a small-scale irrigation system in very few kebeles.

\section{Experimental materials and methodology Materials}

The testing crop was Faba bean (Wolki variety) which is already adapted and still perform best in the study area.

\section{Treatments}

The experiment was done by using three selected Faba bean rhizobial strains based on their performance as recommended by Holeta micro biology laboratory.

1. Control (without both micro nutrient and bacterial rhizobium strain)

2. Faba bean rhizobium strain 17 (EAL 17)

3. Faba bean rhizobium strain 1018 (EAL 1018)

4. Faba bean rhizobium strain 1035 (EAL 1035)

Eighteen $\mathrm{kg} \mathrm{ha}^{-1}$ nitrogen as starter fertilizer and $20 \mathrm{~kg} \mathrm{ha}^{-1}$ phosphorus which is recommended for faba bean in the study district were applied at planting to all plots. Before the experimentation, the viability of inoculates was tested to know whether they are viable or not. Thus, they were found that their number was above $10^{7}$ per one carrier (125 g) and was taken as they are viable. Materials used during inoculation of faba bean with strains was lukewarm water $\left(36{ }^{\circ} \mathrm{C}\right)$ for sticking the strains with faba bean seeds, measuring spoon to take out the strains from the carrier, plastic container to mix the inoculants with the seed and umbrella was used for shading the inoculated seeds from direct sunlight.

\section{Experimental setup}

Carrier peat-based rhizobium strains of faba bean EAL 17, EAL 1018 and EAL 1035 were obtained from Soil Microbiology Laboratory of Holeta Agricultural Research Centre (HARC). First the faba bean seeds were immersed in to lukewarm water so as to create anchoring environment for the Rhaizobium stains. Then under umbrella shade, the bacterial strains were opened and mixed with the faba bean seeds in mixing container. Finally, seeds were allowed to air dry for a few minutes and were planted immediately after air drying. Nitrogen and phosphorus fertilizer were applied at planting by drilling with faba bean seeds in row. The plot size was $3.6 \mathrm{~m}$ length by $3 \mathrm{~m}$ width and spacing between plots and blocks was 1 and $1 \mathrm{~m}$ respectively. The spacing between plants and rows were also 0.1 and $0.4 \mathrm{~m}$ respectively. Ridges were made between each plot to reduce the movement of bacteria and to reduce the leaching/addition of nutrients from plot to plot or from external environment.

\section{Data collection procedures Nodulation}

Sampling for nodulation was performed by excavating the roots of five randomly selected plants in each plot at mid flowering stage of faba bean by destructive sampling from the boarder rows. A hoe was used to dig out the root surrounding soil and the spade was used to excavate the dug soil around $20 \mathrm{~cm}$ depth which is approximately the rooting depth of faba bean, and the radius of approximately $12 \mathrm{~cm}$ extending out from the central stem containing entire root system of the faba bean. The excavated soil was washed from the roots using washing bottle. Nodules from crown region and lateral roots subsequently were removed from the roots and collected in plastic bag for counting. The total number of nodules were counted and the effective and non- effective nodules were counted separately (visual observation) in those five sample plants by taking the intensity of the pink colour into consideration (i.e. nodules which have pink colour is considered as effective nodules) and the effective nodules undergo further analysis like for nodule number, nodule volume and nodule dry weight. The mean values of 
effective nodules from the five plants were recorded as number of nodules per plant.

The collected effective nodules were immersed in previously measured volume of water in a measuring cylinder. The volume of water displaced by the nodules was considered as nodule volume $\left(\mathrm{cm}^{3}\right)$. After the determination of the nodule volume, the collected nodules were dried in an oven for $65 \mathrm{~h}$ at $75{ }^{\circ} \mathrm{C}$ to a constant weight to determine nodule dry weight per plant. The average from five plants was taken as nodule dry weight per plant.

\section{Plant dry matter}

Plant dry matter was determined at mid flowering stage of the crop from plants sampled for nodulation. After the nodules had been collected from roots, the plant samples were placed in a labelled perforated paper bags and ovendried to a constant weight for $65 \mathrm{~h}$ at $75^{\circ} \mathrm{C}$ to determine the plant dry matter. The average dry weight of five plants was measured to determine dry weight per plant.

\section{Plant height}

Five plants from central rows were randomly selected for measuring their height at physiological maturity using measuring tape. The average height of five plants was taken from each plot and was considered as plant height.

\section{Number of pods per plant}

Five plants were randomly selected from harvestable rows of each plot. The pods were collected and counted separately from each plant and their average was taken and reported as number of pods per plant.

\section{Number of grains per pod}

After pods had been counted from each of the five randomly selected non-border plants, grains were separated from pods to get the number of grains per plant. For each plant the number of grains per pod was calculated by dividing the total number of grains per plant with the number of pods per plant. Finally, the mean value of five plants was taken as number of grains per pod.

\section{Biomass yield, grain yield and hundred-grain weight}

At physiological maturity, plants from 4 rows of net plot size $1.6 \times 3 \mathrm{~m}\left(4.8 \mathrm{~m}^{2}\right)$ were manually harvested close to the ground surface. The harvested plant was sun-dried in an open air, and was weighed to determine above ground plant biomass yield. Grain yield of each plot was also determined after threshing. Finally, yield per plot was converted to grain yield per hectare basis. The grain yield was adjusted to $10 \%$ moisture content. The weight of random sample of 100 grains in gram was reported as 100 grain-weight.

\section{Symbiotic effectiveness}

The symbiotic effectiveness of faba bean strains was calculated based on the formula set by Mulongoy (2004) as;

$$
\mathrm{SE}=\frac{\text { InoculatedPlantDM }}{\text { UninoculatedplantDM }}
$$

where, $\mathrm{DM}=$ dry matter in gram, $\mathrm{SE}=$ Symbiotic effectiveness (\%).

The rate of nitrogen-fixing effectiveness is evaluated as highly effective if the value is greater than $80 \%$, effective if it was between 50 to $80 \%$, less effective if the values are between 35 to $49 \%$ and infective when the values were below $35 \%$.

\section{Soil sample collection and processing}

Disturbed composite surface soil samples $(0-30 \mathrm{~cm}$ depth) were collected from experimental area by zigzag sampling method before planting for determination of physico-chemical properties of the soil. Similarly, after harvesting one soil sample from each plot was taken for determination of physico-chemical properties of the soil. Then after, the collected samples were air dried at room temperature and were ground to pass through a $2 \mathrm{~mm}$ sieve for most parameters and through $0.5 \mathrm{~mm}$ sieve to determine total nitrogen and organic carbon. Using core sampler, one soil sample was taken from the representative soil of the study site.

\section{Soil physico-chemical analysis}

Soil samples were analyzed for determination of bulk density, particle size distribution, $\mathrm{pH}$, organic carbon, cation exchange capacity, exchangeable bases $(\mathrm{K}, \mathrm{Ca}$ and $\mathrm{Mg}$ ), base saturation and total nitrogen, from the representative bulk soil sample before planting and available $\mathrm{P}$ two weeks after incubation. Total $\mathrm{N}$ was analyzed for each treatment in all replications following the standard procedure after harvest.

Soil bulk density was estimated by core method up to $30 \mathrm{~cm}$ depth and was calculated as $\rho b=\frac{M s}{V t}$

Where $\rho b$ is the bulk density of the soil $(\mathrm{g} / \mathrm{cm} 3)$, $\mathrm{Ms}=$ Mass of the dry soil $(\mathrm{g})$, and $\mathrm{Vt}=$ total volume of the soil sample $\left(\mathrm{cm}^{3}\right)$ (Blake 1965). Soil pH was determined by potentiometric method at soil: water ratio of 1:2.5 (Van Reewijk 1991). Cation exchange capacity was determined by $1 \mathrm{M}$ ammonium acetate method at $\mathrm{pH}$ 7 (Chapman 1965) whereas organic carbon was determined by the dichromate oxidation method (Walkley and Black 1934) and total nitrogen by the micro kjeldhal method (Jackson 1985), available P was analyzed by Olsen method (Olsen et al. 1954). $\mathrm{Ca}^{++}$and $\mathrm{Mg}^{++}$values 
were analyzed from Atomic Absorption Spectrophotometer reading while $\mathrm{K}^{+}$was determined using flame photometer. Soil particle size distribution was determined by hydrometer method (Bouyoucus 1951).

\section{Partial budget analysis}

The farm gate prices of 12.00 and 1.00 Ethiopian Birr (ETB) were used for faba bean grain and straw price $\mathrm{kg}^{-1}$. One hundred fifty and 160 (ETB) ha ${ }^{-1}$ for EAL 17 and EAL 1018 price respectively were used. Having such prices, the partial budget analysis was done following the CIMMYT procedure (CIMMYT 1988). The mean grain yield used in the partial budget analysis was adjusted to $90 \%$ of the actual yield.

\section{Statistical analysis}

The data measured were subjected to a statistical analysis using SAS software package 2003, version 9.1 for analysis of variance. The LSD mean comparison method at $5 \%$ level of significance was used to separate the significant treatment means.

\section{Results and discussion}

\section{Soil analysis results}

According to Jones (2003), Murphy (1968) and Taddese (1991), the $\mathrm{pH}$ is slightly acidic range (Table 1 ) and such a $\mathrm{pH}$ range is conducive for biological nitrogen fixation (Jordan, 1984). The soil analysis results (Table 1) revealed that the organic matter and total nitrogen was in a range of low and medium respectively (Murphy 1968; Debele 1980; Tadese 1991). Thus, in the study area, the application of nitrogen-containing fertilizer or inoculation with effective strains are mandatory to refill the remaining nitrogen that the soil couldn't supply to the crop. The

Table 1 Soil analysis results of the study site in Wereillu district at planting

\begin{tabular}{ll}
\hline Soil Properties & Values \\
\hline $\mathrm{pH}\left(\mathrm{H}_{2} \mathrm{O}\right)$ & 6.4 \\
Organic matter (OM) (\%) & 1.57 \\
Total Nitrogen (TN) (\%) & 0.21 \\
Available P $\left(\mathrm{mg} \mathrm{kg}^{-1} \mathrm{soil}\right)$ & 8.7 \\
Exchangeable $\mathrm{Ca}\left(\mathrm{cmol}_{\mathrm{C}} \mathrm{kg}^{-1}\right)$ & 38 \\
Exchangeable $\mathrm{Mg}\left(\mathrm{cmol}_{\mathrm{C}} \mathrm{kg}^{-1}\right)$ & 10.2 \\
Exchangeable $\mathrm{K}\left(\mathrm{cmol}_{\mathrm{C}} \mathrm{kg}^{-1}\right)$ & 0.8 \\
Cation exchange capacity $(\mathrm{CEC})\left(\mathrm{cmol}_{\mathrm{C}} \mathrm{kg}^{-1}\right)$ & 58 \\
Bulk density $\left(\mathrm{gm} \mathrm{cm}^{-3}\right)$ & 1.14 \\
Sand \% & 21.5 \\
Silt \% & 23.5 \\
Clay \% & 55 \\
Textural class & Clay \\
\hline
\end{tabular}

available phosphorus was found low (Olsen et al. 1954) and Moderate (Cottenie 1980) and to fill the nutrient P requirement of the crop, the recommended phosphorus fertilizer was added. According to FAO (2006) CEC, exchangeable $\mathrm{Ca}, \mathrm{Mg}$ and $\mathrm{K}$ were in very high range and no need to apply any one of them in the study site. The bulk density of the soil laid in a range of moderate according to (Hazelton and Murphy 2007) and nitrogen fixation is not more difficult to take place under such bulk density.

As it is indicated in Table 2, after harvesting total nitrogen across all treatments fall under the same nitrogen ratting range (medium) (Debele 1980; Tadesse 1991). But numerically, the nitrogen content of the soil after harvesting is better than the nitrogen content of the soil before planting. This may be due to the addition of nitrogen into the soil as nitrogen passes into the soil itself, either by excretion or more probably by sloughing off of the roots and especially of the nodules (Brady and Weils 2008).

\section{Effect of inoculation on nodulation parameters Nodule number}

As it indicated in Table 3, inoculation of strains significantly $(P \leq 0.05)$ affected nodule number/plant. The higher nodule number was obtained from inoculation of strain EAL 1018 despite it is not statistically significant

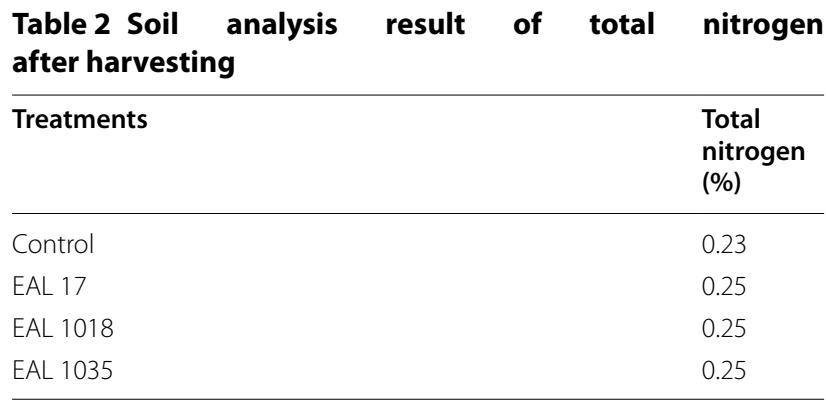

EAL Ethiopian agricultural legumes

\section{Table 3 Effect of inoculation on nodulation parameters}

\begin{tabular}{llll}
\hline Strains & Nodule number & Nodule volume & Nodule dry weight \\
\hline O EAL & $49.067^{\mathrm{b}}$ & $0.6333^{\mathrm{b}}$ & $0.2400^{\mathrm{c}}$ \\
EAL 17 & $63.767^{\mathrm{a}}$ & $1.0000^{\mathrm{a}}$ & $0.3067^{\mathrm{b}}$ \\
EAL 18 & $69.400^{\mathrm{a}}$ & $1.1333^{\mathrm{a}}$ & $0.3867^{\mathrm{a}}$ \\
EAL 1035 & $64.800^{\mathrm{a}}$ & $1.0667^{\mathrm{a}}$ & $0.3267^{\mathrm{a}, \mathrm{b}}$ \\
LSD (0.05) & 11.112 & 0.1597 & 0.0610 \\
CV & 9.01 & 8.34 & 9.70 \\
SE $( \pm)$ & 3.2113 & 0.0461 & 0.0176 \\
\hline
\end{tabular}

Where EAL Ethiopian Agricultural Legumes, CV Coefficient of variation, LSD Least significant difference, SE standard error 
compared to EAL 17 and EAL 1035. This result implies that inoculation of those strains may best suited in the study area compared to the existing faba bean rhizobium strains to bust the nodule number. The result is in line with the findings Alemayehu Workalemahu (2009) and Nagwa et al. (2012) who reported that inoculation of rhizobium strain to faba bean significantly increased nodule number. Desta et al. (2015) also reported that inoculation of faba bean rhizobium strains significantly increase nodule number/plant. But in contrary this work, Endalkachew Fekadu et al. (2018) reported that faba bean plants which were not inoculated with rhizobium formed nodules with a higher number as compared with plants inoculated and received the same treatment.

\section{Nodule volume}

In Table 3 nodule volume was significantly $(P \leq 0.05)$ affected by rhizobium strain. The highest nodule volume $\left(1.1333 \mathrm{~cm}^{3} /\right.$ plant $)$ was recorded from the inoculation of strain EAL 1018 although it was statistically insignificant with inoculation of EAL 17 and EAL 1035. The only statistically significant difference was observed when the control is compared to the faba bean rhizobium strains. As Rodelas et al. (1999) described as while using strains nodule dry weight accumulation increased, this work also showed that inoculation of strains increased nodule volume. Thus, the increment in volume in this work may be due to the increment of nodule number and nodule dry weight as inoculation of faba bean strains.

\section{Nodule dry weight}

Nodule dry weight significantly affected by the strains as indicated in Table 3 . The highest nodule dry weight $(0.3867 \mathrm{~g} /$ plant $)$ was recorded with the inoculation of faba bean strain EAL 1018 followed by the faba bean EAL 1035 and EAL 17 respectively. This result revealed that, inoculation of faba bean with rhizobial strains gave significantly higher nodule dry weight compared to the control treatment. This result agrees with the result reported by El-Wakeil and El-Sebai (2007) who stated that application of rhizobium strains brought significantly higher nodule dry weight and nodule number. Rodelas et al. (1999) also reported that nodule dry weight was significantly increased (38-53\%) by co inoculation with strains. This augmentation in nodule dry weight may be due to large size of nodules and increased number of nodules through the infection threads of the inoculated faba bean.

\section{Symbiotic effectiveness}

The result of the symbiotic effectiveness (Table 4) revealed that application of all the three faba bean rhaizobium strains in the study area were highly effective based on the formula that was developed by Mulongoy (2004).
Table 4 The effect inoculation of faba bean on symbiosis effectiveness of Rhaizobium strains at study site

\begin{tabular}{lccl}
\hline Treatment & Plant dry weight & Percentage (\%) SE & Effectiveness \\
\hline Un-inoculated & 8.013 & - & - \\
EAL 17 & 9.473 & 118.2 & HE \\
EAL 1018 & 10.610 & 132.4 & HE \\
EAL 1035 & 9.347 & 116.6 & HE \\
\hline
\end{tabular}

Where EAL Ethiopian Agricultural Legumes, SE Symbiosis effectiveness and $H E$ Highly effective

This implies that inoculation of faba bean rhaizobium strain EAL 17, EAL 1018 and EAL 1035 creates high symbiotic association with the host plant, faba bean than the existing rhaizobium strains in the study district. This result supported by previous findings of Gebremariam and Assefa (2018) in such a way that the symbiotic effectiveness of isolates of faba bean rhaizobium strains were highly effective.

\section{Effect inoculations and micronutrients on agronomic parameters \\ Plant height}

Strain inoculation significantly affected $(P \leq 0.05)$ plant height. As a result, faba bean inoculation with rhaizobium strain EAL1018 gave higher $(61.733 \mathrm{~cm})$ plant height compared to the other treatments and statistically significant compared to the control and EAL17 (Table 5). This could be attributed to inoculation of rhaizobium strains to faba began supplying additional nitrogen through symbiotic nitrogen fixation and lead to increased plant height. This result agreed with the result of Farfour (2013) which affirmed that application of rhizobium stains could increase plant height of faba bean. Similarly, El-Azeem et al. (2007) reported that application of bacterial strain significantly increases plant height compared to the uninoculated treatments.

\section{Plant dry weight}

The data on plant dry weight (Table 5) showed that inoculation of faba bean with EAL1018 alone gave higher $(10.610 \mathrm{~g})$ plant dry weight but statistically only the control $(8.013 \mathrm{~g})$ is the lowest dry weight from the uninoculated treatment. Our result is supported by Farfour (2013) who reported that, inoculation of faba bean with rhizobial strain caused noticeable increase in plant length, fresh weight and dry weight. Sameh et al. (2017) also reported that inoculation of strains increases plant dry weight. 
Table 5 Effects of rhizobium inoculation on yield related parameters of faba bean (plant height $(\mathrm{cm})$, biomass weight (kg $\mathrm{ha}^{-1}$ ), plant dry weight (g/plant), number of pod/plants, $100 \mathrm{seed}$ weight(g) and number of seed/pod)

\begin{tabular}{lllllll}
\hline Strains & Plant height & $\begin{array}{l}\text { Number of pod/ } \\
\text { plants }\end{array}$ & Plant dry weight & $\begin{array}{l}\text { Number of seed/ } \\
\text { pods }\end{array}$ & 100 seed weight & Biomass weight \\
\hline O EAL & $51.600^{\mathrm{b}}$ & $19.400^{\mathrm{b}}$ & $8.013^{\mathrm{b}}$ & $2.1333^{\mathrm{b}}$ & $51.600^{\mathrm{b}}$ & $7327^{\mathrm{c}}$ \\
EAL 17 & $56.533^{\mathrm{a}, \mathrm{b}}$ & $24.467^{\mathrm{a}}$ & $9.473^{\mathrm{a}, \mathrm{b}}$ & $2.2667^{\mathrm{a}, \mathrm{b}}$ & $54.400^{\mathrm{a}, \mathrm{b}}$ & $8329^{\mathrm{bc}}$ \\
EAL 18 & $61.733^{\mathrm{a}}$ & $24.200^{\mathrm{a}, \mathrm{b}}$ & $10.610^{\mathrm{a}}$ & $2.4667^{\mathrm{a}}$ & $56.400^{\mathrm{a}}$ & $10277^{\mathrm{a}}$ \\
EAL 1035 & $59.200^{\mathrm{a}}$ & $25.000^{\mathrm{a}}$ & $9.347^{\mathrm{a}, \mathrm{b}}$ & $2.4000^{\mathrm{a}, \mathrm{b}}$ & $56.467^{\mathrm{a}}$ & $9361^{\mathrm{a}, \mathrm{b}}$ \\
LSD (0.05) & 5.2662 & 4.8597 & 2.5721 & 0.2746 & 3.7855 & 1270.9 \\
CV & 4.60 & 10.45 & 13.75 & 5.93 & 3.46 & 7.21 \\
SE $( \pm)$ & 1.5218 & 1.4044 & 0.7433 & 0.0793 & 1.0939 & 367.27 \\
\hline
\end{tabular}

Means with the same letter are not significant

Where EAL Ethiopian Agricultural Legumes, CV Coefficient of variation, LSD Least significant difference, SE standard error

Table 6 Effect of rhizobium inoculation on grain yield of faba bean $\left(\mathrm{kg} \mathrm{ha}^{-1}\right)$

\begin{tabular}{ll}
\hline Strains & Grain yield \\
\hline O EAL & $2614.5^{\mathrm{d}}$ \\
EAL 17 & $2995.1^{\mathrm{c}}$ \\
EAL 18 & $3806.5^{\mathrm{a}}$ \\
EAL 1035 & $3411.7^{\mathrm{b}}$ \\
LSD (0.05) & 333.47 \\
CV & 5.20 \\
SE $( \pm)$ & 96.366
\end{tabular}

Where EAL Ethiopian Agricultural Legumes, CV Coefficient of variation, LSD Least significant difference, SE standard error

\section{Number of pod/plants}

The number of pods/plants was affected by the inoculation of the all EAL17, EAL1018 and EAL1035 rhaizobium strains. Accordingly, inoculation of those three faba bean brought statistically significant $(P \leq 0.05)$ difference compared to the un-inoculated treatment (Table 5). This increment in could be attributed to the increment of faba bean plant height. The research conducted by Yohannes Desta et al., (2015) reported that rhizobial strain alone could significantly increase number of pods/plants.

\section{Number of seed/pods}

As it is indicated in Table 5, inoculation of rhaizobium strains statistically affected number of seeds /pods as compared to the un-inoculated treatment. This finding disagreed with the finding of Zerihun and Abera (2014) who indicated that inoculation of rhizobial strain did not impose significant difference over the un-inoculated one (Table 6).

\section{0 seed weight}

The result indicated a marked difference in terms of 100 seed weight. It was observed that rhaizobium strains significantly affected $(P \leq 0.05) 100$ seeds weight (Table 5). All faba bean rhaizobium strain, gave statistically significant difference over the control. This result was in line with the work of El-Wakeil and El-Sebai (2007) who reported that inoculation of faba bean with rhizobial strain alone could increase 100 seed weight. In contrary with this result, the finding of Bolland et al. (2000) stated that inoculation of faba bean rhaizobium strains didn't brought significant seed weight difference on faba bean. The weight difference gained from this work could be attributed the effect of the grain filling ability of nitrogen through nitrogen biological fixation.

\section{Biomass yield}

Rhaizobium strains significantly $(P \leq 0.05)$ affected biomass weight. From (Table 5) it is indicated that EAL1018 gave maximum $\left(10277 \mathrm{~kg} \mathrm{ha}^{-1}\right)$ biomass yield while the lowest biomass yield was obtained from the control treatment. EAL1018 significantly influenced faba bean biomass weight compared to EAL17 and the un-inoculated treatment. This result is in agreement with the work of El-Azeem et al. (2007) in a way that, inoculation of bacterial rhaizobium strain cause a significant above ground biomass on faba bean. The biomass yield difference obtained from the inoculation of faba bean rhaizobium strains could be from the additional supply of nitrogen through the remarkable biological nitrogen fixation by the inoculated strains.

\section{Grain yield}

The grain yield of faba bean was significantly $(P \leq 0.05)$ influenced by inoculation of EAL 1018, EAL1035 and EAL17. As it is shown in Table 6 the maximum grain yield $\left(3806.5 \mathrm{~kg} \mathrm{ha}^{-1}\right)$ was obtained from the inoculation of EAL1018 whereas the lowest grain yield was obtained from the control. The result revealed that application of faba bean rhizobium strain, EAL1018 
Table 7 Pearson's correlation coefficient among yield and yield related parameters under strain and micronutrient treatments

\begin{tabular}{|c|c|c|c|c|c|c|c|c|c|}
\hline & GY & BIWt & NDWt & NN & NP & NS & NV & PDWt & $\mathrm{PH}$ \\
\hline \multicolumn{10}{|l|}{ GY } \\
\hline BIWt (r) & 0.973 & & & & & & & & \\
\hline$p$-value & $* * *$ & & & & & & & & \\
\hline \multirow[t]{2}{*}{ NDWt } & 0.7856 & 0.7741 & & & & & & & \\
\hline & $* * *$ & $* * *$ & & & & & & & \\
\hline \multirow[t]{2}{*}{ NN } & 0.8133 & 0.7804 & 0.8545 & & & & & & \\
\hline & $* * *$ & $* * *$ & $* * *$ & & & & & & \\
\hline \multirow[t]{2}{*}{ NP } & 0.5812 & 0.5914 & 0.3319 & 0.4912 & & & & & \\
\hline & * & * & Ns & Ns & & & & & \\
\hline \multirow[t]{2}{*}{ NS } & 0.7912 & 0.7897 & 0.598 & 0.7307 & 0.2895 & & & & \\
\hline & $* * *$ & $* * *$ & * & $* *$ & ns & & & & \\
\hline \multirow[t]{2}{*}{ NV } & 0.6246 & 0.6637 & 0.8353 & 0.7156 & 0.5825 & 0.4879 & & & \\
\hline & $* *$ & $* *$ & $* * *$ & $* *$ & * & ns & & & \\
\hline \multirow[t]{2}{*}{ PDWt } & 0.6525 & 0.721 & 0.5122 & 0.6522 & 0.4126 & 0.8259 & 0.5665 & & \\
\hline & $*$ & $* *$ & Ns & * & ns & $* * *$ & ns & & \\
\hline \multirow[t]{2}{*}{$\mathrm{PH}$} & 0.8164 & 0.8439 & 0.5884 & 0.6001 & 0.81 & 0.5878 & 0.676 & 0.6643 & \\
\hline & $* *$ & $* * *$ & * & * & $* *$ & $*$ & * & * & \\
\hline \multirow[t]{2}{*}{ Sedwt } & 0.7385 & 0.754 & 0.3314 & 0.5553 & 0.6815 & 0.4831 & 0.2227 & 0.4097 & 0.705 \\
\hline & $* *$ & $* *$ & Ns & Ns & * & ns & ns & ns & * \\
\hline
\end{tabular}

Where GY Grain yield, BIWt Biomass weight, PH Plant height, NN Nodule number, NV Nodule volume, NDWt. nodule dry weight, PDWt. Plant dry weight, NP Number of pods, NS Number of seed and SDWt. $100 \mathrm{~g}$ seed weight, ns No significant correlation, ${ }^{*}$ Significant correlation $(P 0.05$ but 0.01$)$ and $* *$ Highly significant correlation $(P$ 0.01)

gave a grain yield advantage of 45.6, 27.1 and 10.4\% over the un-inoculated, EAL17, and EAL1035 treatments respectively. This work agrees with the work of Rugheim and Abdelgani (2012) who indicated that co inoculation of rhizobial strains significantly increased faba bean grain yield. The finding of Yohannes Desta et al. (2015) was also in line with this finding in a way that application of effective rhizobium strain alone and/ or in combination with zinc significantly increased grain yield of faba bean. Sameh et al. (2017) reported that application of effective strains increases grain yield of faba bean up to $44-47 \%$. Unlike the above-mentioned findings, Zerihun and Abera (2014) reported that rhizobium inoculation didn't increase faba bean grain yield over the control. The increments in grain yield due to inoculation of rhizobium strains indicated that the soils nitrogen is a limiting factor and the existing rhizobium bacteria may not capable to supply nitrogen through biological nitrogen fixation. Thus, the grain yield could be strongly improved by means of inoculation or fertilization.

The correlation analysis (Table 7) indicated that there was highly positively significant $(P \leq 0.01)$ correlation grain yield with yield related parameters. The correlation coefficient value of all parameters in relation to the grain yield of faba bean was almost more than 0.5 especially there was a strong correlation $(r=0.96)$ between the grain yield and the biomass yield of faba bean.

Table 8 Partial budget analysis of the variable costs on mean grain and straw yields of faba bean in the study district for strains and micronutrients

\begin{tabular}{|c|c|c|c|c|c|c|c|c|c|c|c|}
\hline Treatments & AGY & GYP & ASY & SYP & TR & $\mathrm{SC}$ & $\mathrm{LC}$ & TVC & NB & $\mathrm{DA}$ & MRR \\
\hline Control & 2353.1 & 12 & 4712.5 & 1 & $32,949.1$ & 0 & 0 & 0 & $32,949.1$ & & \\
\hline EAL 17 & 2695.6 & 12 & 5333.9 & 1 & $37,680.9$ & 150 & 400 & 550 & $37,131.0$ & & 760.3 \\
\hline EAL 1018 & 3425.9 & 12 & 6470.5 & 1 & $47,580.7$ & 160 & 400 & 560 & $47,020.7$ & & $98,897.0$ \\
\hline EAL 1035 & 3070.5 & 12 & 5949.3 & 1 & $42,795.6$ & 160 & 400 & 560 & $42,235.7$ & $D$ & \\
\hline
\end{tabular}

All costs are expressed in Ethiopian birr (ETB). AGY Adjusted grain yield $\left(\mathrm{kg} \mathrm{ha}^{-1}\right)$, GYC Grain yield price kg $^{-1}(\mathrm{ETB}), \mathrm{ASY}_{\mathrm{Adjusted}} \mathrm{straw}$ yield $\left(\mathrm{kg}\right.$ ha $\left.{ }^{-1}\right), \mathrm{SYP}=\mathrm{Straw}$ yield price $\mathrm{kg}^{-1}$ (ETB), TR Total revenue (ETB), SC Strain cost $\mathrm{kg}^{-1}$ (ETB), LC Labor cost (ETB), TVC Total variable cost, NB Net benefit (ETB), DA dominance Analysis, D Dominated, MRR Marginal rate of return 


\section{Partial budget analysis}

The partial budget analysis for marginal rate of return (Table 8) showed that faba bean rhizobium strains EAL 1018 and EAL 17 gave acceptable marginal rate of return (i.e., MRR greater than 100\%). According to CIMMYT (1988) when there are two and more treatments with MRR greater than $100 \%$, the treatment with greater net benefit should be selected for recommendation. Therefore, application of EAL 1018 brought the maximum net benefit (47020.7 Ethiopian Birr) per hectare while possessing MRR of greater than $100 \%$ and thus it is economically feasible for Wereillu district.

\section{Conclusions and recommendations}

Biological nitrogen fixation through microbial processes ensures the greatest quantitative impact on the nitrogen cycle and has tremendous potential for the contribution of fixed $\mathrm{N}$ in the soil. Accordingly, this research work was conducted to examine this remarkable activity of rhizobium strains under field conditions. As indicated from the result, rhizobial inoculants significantly $(P \leq 0.05)$ affected yield and yield components of faba bean. Rhizobium strains brought statistically significant difference on nodulation of faba bean like nodule number, nodule volume, and nodule dry weight of faba bean.

From the result, inoculation of faba bean strain, EAL1018 brought biologically higher significant grain and biomass yield and also economically maximum net benefit compared to other treatments. Thus EAL-1018 could be recommended in the study district and similar agro ecological zones.

\section{Abbreviations}

CIMMYT: International Maize and Wheat Improvement Centre; CV: Coefficient of Variation; DMRT: Duncan's Multiple Range Test; EAL: Ethiopian Agricultural Legumes; ETB: Ethiopian Birr; RCBD: Randomized Complete Block Design; SAS: Statistical Analysis System.

\section{Acknowledgements}

The authors acknowledge supports provided by Amhara Agricultural Research Institute (AARI) for their continuous follow-up for the field works.

\section{Authors' contributions}

SG carried out the field work, performed the statistical analysis, and drafted the manuscript. ET coordinated the study, contributed to the write up of the manuscript. TB coordinated the study, contributed to the write up of the manuscript. All authors read and approved the final manuscript.

\section{Funding}

Not applicable.

\section{Availability of data and materials}

Supporting data will be made available in a publicly accessible data repository (e.g. 3TU Data centrum: http://data.3tu.nl/repository).

Ethics approval and consent to participate Not applicable.
Consent for publication

Not applicable.

\section{Competing interests}

The authors declare that they have no competing interests.

\section{Author details}

1 Department of Natural Resource Management, Soil science, Sirinka Agricultural Research Center, P.O. Box 74, Woldiya, Ethiopia. ${ }^{2}$ Department of Natural Resource Management, Bahir Dar University, Bahir Dar, Ethiopia. ${ }^{3}$ Amhara Agricultural Research Institute, Bahir Dar, Ethiopia.

Received: 1 September 2020 Accepted: 11 January 2021

Published online: 22 February 2021

\section{References}

Blake CA. Methods of soil analysis. Part I. Madison: American Society of Agronomy; 1965.

Bolland MDA, Siddique KHM, Brennan RF. Grain yield responses of faba bean (Vicia faba L.) to applications of fertiliser phosphorus and zinc. Aust J Exp Agric. 2000;40:849.

Bouyoucus CJ. A reclamation of the hydrometer method for making mechanical analysis of soils. Agron J. 1951;43(434):438.

Brady NC, Weil RR. The nature and properties of soils. 14th ed. Ohio: Pearson Prentice hall; 2008. p. 965

Chapman HD. Cation exchange capacity. Ensminger: Black; 1965. p. 891-901.

CIMMYT (International Maize and Wheat Improvement Centre). From agronomic data to farmers recommendations: an economic training manual. Revised. Mexico: CIMMYT; 1988. p. 200.

Cottenie A. Soil and plant testing as a basis of fertilizer recommendations. FAO Soil Bulletin 38/2. Rome: Food and Agriculture Organization of the United Nations; 1980.

CSA (Central Statistical Agency). Area and production of major Crops. Addia Ababa: The Federal Democratic Republic of Ethiopia Central Statistical Agency; 2018.

Debele B. The physical criteria and their rating proposed for land evaluation in the highland region of Ethiopia. Addis Ababa: Land Use Planning and Regulatory Department Ministry of Agriculture; 1980

Desta Y, Habtegebrial K, Weldu Y. Innoculation, Phosphorus and zinc fertilizer rates on nodulation, yield and nutrient uptake of faba bean (Vica faba L.) grown on Calcaric Cambi soil of semiarid Ethiopia. J Soil Sci Enivron Manag. 2015;6:9-15.

Duc G, Bao S, Bamu M, Redden B, Sadiki M, Suso MJ, Vishniakova M, Zong $X$. Diversity maintenance and use of (Vicia faba L). genetic resources. ELSEVIER. 2010;115:270-8.

EL-Azeem SAA, Mehana TA, Shabayek AA. Response of faba bean (Vicia faba L.) to inoculation with plant growth-promoting rhizobacteria. CATRINA. 2007;2:67-75.

EL-Wakeil NE, EL-Sebai TN. Role of biofertilizer on faba bean growth, yield and its effect on bean aphid and the associated predators. Res J Agric Biol Sci. 2007:3:800-7

FAO (Food and Agriculture Organization). World reference base for soil resources. World soil resources reports. Rome: FAO; 1984.

FAO (Food and Agriculture Organization). Plant nutrition for food security. A guide for integrated nutrient management. Rome: FAO; 2006.

Farfour AS. Enhancement of the growth and phenolic content of faba bean (Vicia faba L.) by applying some biofertilizer agents. J Food Stud. 2013. https://doi.org/10.5296/jfs.v2i1.4425

Fekadu E, Kibret K, Melese A, Bedadi B. Yield of Faba bean (Vicia faba L.) as affected by lime, mineral $P$, farmyard manure, compost and rhizobium in acid soil of Lay Gayint district, northwestern highlands of Ethiopia. Ethiopia: Agriculture and Food Security; 2018.

Fujita H, Aoki S, Kawaguchi M. Evolutionary dynamics of nitrogen fixation in the legume-rhizobia symbiosis. PLoS ONE. 2014;9:93670.

Gebremariam A, Assefa F. The effect of inter cross-inoculation host group rhizobia on the growth and nitrogen fixation of faba Bean (Vicia faba L.) varieties in North Showa, Amhara Regional State, Ethiopia. J Agric Biotechnol Sustain Dev. 2018;10:25-33. 
Hailu E, Getaneh G, Sefera T, Tadesse N, Bitew B, Boydom A, Kassa D, Temesgen T. Faba bean gall; a new threat for faba bean (Vicia faba L.) production in Ethiopia. Adv Crop Sci Tech. 2014;2:144.

Hanelt P, Mettin D. Biosystematics of the genus Vicia (Leguminosae). Annu Rev Ecol Syst. 1989;20:199-223.

Hazelton P, Murphy B. Interpreting Soil Test Results. 2nd ed. Australia: CSIRO Publishing; 2007. p. 152p.

Herridge DF, Peoples MB, Boddey RM. Global inputs of biological nitrogen fixation in agricultural systems. Plant Soil. 2008:311:1-18.

Jackson I. The role of phosphorus in nitrogen fixation by young pea plants (Pisum sativum L.). Plant Physiol. 1985;64:190-6.

Jones JB. Agronomic handbook, management of crops, soils, and their fertility. Boca Raton: CRC Press LLC; 2003. p. 482.

Jordan DC. Rhizobiumceae. In: Krieg N, Holt JG, editors. Bergey's manual of systematic bacteriology. Baltimore: Williams and Wilkins; 1984. p. 235-56.

Kogal L, Fisseha S, Bendic R, Reilinge R, McClusky S, King R, Solomon T. Litospheric strength and strain localization in continental extension from observation of east Africa Rift. Adv Earth Space Sci. 2012. https://doi. org/10.1029/2011JB008516.

Mulongoy K. Technical paper 2, Biological nitrogen fixation. Can J Microbiol. 2004;21(1):19.

Murphy HF. A report on fertility status and other data on some soils of Ethiopia. College of Agriculture HSIU. Experimental Station Bulletin No. 44. Alemaya: College of Agriculture; 1968. p. 551.

Nagwa E-K, Shalaby ME, Belal EB, Gremi SME. Symbiotic nitrogen fixation of faba bean plants inoculated with salt-tolerant rhizobium isolates. J Agric Chem and Biotechn. 2012:3:411-23.

Olsen SR, Cole FS, Dean LA. Estimation of available phosphorus in soils by extraction with sodium bicarbonate. Washington: USDA Circ. No. 939; 1954

Rodelas B, GonzaLez-LoPez J, Pozo C, Salmero V, Mart MV, Toledo N. Response of faba bean (Vicia faba L.) to combined inoculation with Azotobacter and Rhizobium leguminosarum bv. viceae. Appl Soil Ecol. 1999;12:51-9.

Rugheim AME, Abdelgani ME. Effects of microbial and chemical fertilization on yield and seed quality of faba bean (Vicia faba). Int Food Res J. 2012;19:417-22.

Sameh H, Youseif FH, El-Megeed A, Saleh AS. Improvement of faba bean yield using rhizobium/agrobacterium inoculant in low-fertility sandy soil. Agronomy MDP. 2017. https://doi.org/10.3390/agronomy7010002.
Santos PC, Fang Z, Mason SW, Setubal JC, Dixon R. Distribution of nitrogen fixation and nitrogenase-like sequences amongst microbial genomes. BMC Genomics. 2012;13:162.

SAS (Statistical Analysis System). Statistical Analysis System, version 9.1. Cary: SAS Institute Inc; 2003.

Siczek A, Lipiec J. Impact of aba bean-seed rhizobial inoculation on microbial activity in the rhizosphere soil during growing season. Int J Mol Sci. 2016. https://doi.org/10.3390/ijms17050784.

Sullivan DMO, Angra D. Advances in faba bean genetics and genomics. Genet Front. 2016;7:150

Tadese T. Soil, plant, water, fertilizer, animal manure and compost analysis. Working Document No 13. Addis Ababa: International Livestock Research Center for Africa; 1991.

Tefera M, Chernet T, Haro W. Geological Map of Ethiopia. Ethiopia: Ministry of Mines Geological Survey of Ethiopia GSE; 1996

Van Reewijk LP. Procedures for soil analysis. In: Clark FE, editor. Methods of soil analysis. Agronomy No. 9. 3rd ed. International Soil Reference Center (ISRIC): Wageningen; 1992.

Walkley A, Black IA. An example of the digestion method for determining soil organic matter and a proposed modification of the chromic acid titration method. Soil Sci. 1934;34:29-38.

Workalemahu A. The effect of indigenous root-nodulating bacteria on nodulation and growth of faba bean (vicia faba L.) in the low-input agricultural systems of Tigray highlands, northern Ethiopia. CNCS. 2009;1:30-43.

Yadav J, Verma JP. Effect of seed inoculation with indigenous Rhizobium and plant growth promoting rhizobacteria on nutrients uptake and yields of chickpea (Cicer arietinum L.). Eur J Soil Biol. 2014;63:70-7.

Zerihun A, Abera T. Yield response of faba bean to fertilizer rate, rhizobium inoculation and lime rate at Gedo highland, Western Ethiopia. Global Sci Res J. 2014;2:135-9.

\section{Publisher's Note}

Springer Nature remains neutral with regard to jurisdictional claims in published maps and institutional affiliations.
Ready to submit your research? Choose BMC and benefit from:

- fast, convenient online submission

- thorough peer review by experienced researchers in your field

- rapid publication on acceptance

- support for research data, including large and complex data types

- gold Open Access which fosters wider collaboration and increased citations

- maximum visibility for your research: over $100 \mathrm{M}$ website views per year

At $\mathrm{BMC}$, research is always in progress.

Learn more biomedcentral.com/submissions 